fra den lukkede gruppen «Fatigue etter kreftbehandling» på Facebook som «Dette kjenner jeg meg igjen i» og «Nå slipper jeg å forklare for legen, jeg kan bare legge frem denne artikkelen». Lykke til videre med den flotte jobben dere gjør som kreftkoordinatorer.

Tone Kind Brekke

tonekindbrekke@hotmail.com

Tone Kind Brekke (f. 1958) har merkantil bakgrunn.

Ingen oppgitte interessekonflikter.

\section{Re: God løsning på reservasjonssaken}

Løsningen helseministeren har foreslått i reservasjonssaken, som Gjessing kommenterer i sin leder (1), åpner for at kvinnen selv kan velge hvem hun vil søke råd hos i en vanskelig livskrise. Et av alternativene er å bruke fastlegen, slik kun ca $10 \%$ av kvinnene i Oslo har gjort de siste årene. De fleste unge har andre de søker råd hos, som helsesøster, skolehelsetjenesten og helsestasjon for ungdom, eller andre de har tillit til.

Videre åpner denne løsningen for at leger med samvittighetsvansker kan fokusere på å gi best mulig faglige råd til kvinnen, uten å måtte sette sin underskrift på et papir. Juridisk sett er en underskrift en nokså klar ansvarlig handling. En samtale i tillit og respekt mellom en myndig kvinne og en klok lege (eller helsesøster) er ikke annet enn god medisin. Det gjenstår å se om helseminister Bent Høie klarer å formulere dette på en god og klar måte.

\section{Arnulf Heimdal}

arnulfheimdal@gmail.com

Arnulf Heimdal (f. 1957) er fastlege og universitetslektor i Oslo.

Ingen oppgitte interessekonflikter.

Litteratur

1. Gjessing H. God løsning på reservasjonssaken. Tidsskr Nor Legeforen 2014; 134: 1107

\section{Re: Østrogentilskudd og forskningsparadigmer}

Det vises til vår forrige kommentar til denne artikkelen (1) og tilsvarene fra Johan Halse (2) og Erik Fink Eriksen (3). Vi spurte på bakgrunn av den reitererte egenerklæringen om «ingen oppgitte interessekonflikter» og svært avvikende opplysninger i et engelskspråklig gynekologitidsskrift - om det hadde skjedd feil i Halses og Fink Eriksens innrapportering av interessekonflikter, eller om vi hadde misforstått regelverket. Svarene er tankevekkende: Halse tar opp spørsmålet om når en interessekonflikt foreldes, og Fink Eriksen skriver at «På tidspunktet for publiseringen av vårt tilsvar (...) hadde «advisory board» for Novo Nordisk vært oppløst i mer enn to år».

Tidsskriftets skjema for deklarering av interessekonflikter angir at interessekonflikter som går inntil 36 måneder tilbake i tid skal innrapporteres. Samtidig kan man også diskutere om treårsgrensen er tilstrekkelig: I andre sammenhenger, for eksempel når det gjelder oppdrag for den europeiske legemiddelmyndigheten (EMA), er tidsvinduet fem år (4). Her bes man i tillegg om å angi industrirelasjoner som er eldre enn fem år «in the context of increased transparency».

Det bør også ses nærmere på begrepet «relevant financial activites outside the submitted work» i Tidsskriftets interessekonfliktskjema. Halse skriver at han ikke deklarerte interessekonflikter fordi han de siste tre årene kun hadde hatt oppdrag for produsenten av osteoporosemidlet denosumab. Fink Eriksen anfører at interessekonfliktene i gynekologitidsskriftet ble angitt fordi artikkelen dreide seg om osteoporosebehandling generelt, slik at disse interessekonfliktene ikke var relevante for leserinnlegget om østrogenterapi i Tidsskriftet. Imidlertid dreier alt dette seg om behandling eller forebygging av postmenopausale plager/sykdommer.

Regelverket eksemplifiseres på følgende måte i Tidsskriftets skjema: Hvis man skriver om behandling med et legemiddel som blokkerer epidermal vekstfaktor-reseptor (EGFR) ved lungekreft, skal all aktivitet på hele kreftområdet deklareres, ikke bare det som er relatert til EGFR-blokkere eller til lungekreft (4). En tidligere operativ versjon av interessekonfliktskjemaet inneholdt i tillegg en nyttig oppfordring om å «err on the side of full disclosure».

Tidsskriftet er tilsluttet «International Committee of Medical Journal Editors», som i sitt regelverk blant annet presiserer at «When authors submit a manuscript, whether an article or a letter, they are responsible for disclosing all financial and personal relationships that might bias their work. To prevent ambiguity, authors must state explicitly whether potential conflicts do or do not exist» (5). Opplysningsplikten er altså ikke valgfri, går minimum tre år tilbake $\mathrm{i}$ tid og gjelder alle - $\mathrm{i}$ vid forstand - relasjoner innenfor et terapiområde. Tidsskriftets redaktør har tidligere kommentert mangelen på transparens når det gjelder interessekonflikter i biomedisinske tidsskrifter, og har oppfordret sine lesere til å la «absolutt alt komme frem i lyset» (6).

Vi finner det betimelig å stille to spørsmål: Bør Tidsskriftets redaktør nå komme på banen og presisere hvordan regelverket skal praktiseres, og bør eventuell manglende etterlevelse føre til sanksjoner?

\section{Lars Slørdal \\ lars.slordal@ntnu.no \\ Olav Spigset}

Lars Slørdal (f. 1955) er dr.med., professor og overlege ved Institutt for laboratoriemedisin, barne- og kvinnesykdommer, Norges teknisk-naturvitenskapelige universitet/St. Olavs hospital.

Ingen oppgitte interessekonflikter.

Olav Spigset (f. 1963) er dr.med., overlege og professor ved St. Olavs hospital/Institutt for laboratoriemedisin, barne- og kvinnesykdommer, Norges teknisk-naturvitenskapelige universitet.

Ingen oppgitte interessekonflikter.

Litteratur

1. Slørdal L, Spigset O. Interessekonflikter og forskningsparadigmer. Tidsskr Nor Legeforen 2014; 134: 272

2. Halse J. Interessekonflikter og forskningsparadigmer. Tilsvar. Tidsskr Nor Legeforen 2014; 134: 272

3. Fink Eriksen E. Interessekonflikter og forskningsparadigmer. Tilsvar. Tidsskr Nor Legeforen 2014; 134: 272-3.

4. European Medicines Agency. Public declaration of interest and confidentiality undertaking of European Medicines Agency (EMA) scientific committee mem bers and experts. www.ema.europa.eu/docs/en_GB/document_library/ Template or form/2011/07/WC500109480.pdf (4.4.2014).

5. Uniform Requirements for Manuscripts Submitted to Biomedical Journals Ethical Considerations in the Conduct and Reporting of Research: Conflicts of Interest. http://icmje.org/about-icmje/faqs/icmje-recommendations (4.4.2014).

6. Haug C. En solskinnshistorie. Tidsskr Nor Legeforen 2010; 130: 919.

\section{Redaktøren svarer:}

Lars Slørdal \& Olav Spigset stiller meg to spørsmål om interessekonflikter som jeg gjerne vil svare på. På et overordnet plan følger Tidsskriftet anbefalingene fra the International Committee of Medical Journal Editors (ICMJE) (1). Tidsskriftet er ikke bare tilsluttet denne organisasjonen, men har vært med på å utvikle ICMJEs retningslinjer i snart 30 år. Da er det en selvfølge at vi selv følger anbefalingene.

Når det gjelder hvordan regelverket skal praktiseres, har Slørdal $\&$ Spigset $\mathrm{i}$ all hovedsak redegjort godt for dette. Noen få presiseringer: ICMJEs retningslinjer gjennomgikk en omfattende revisjon i 2012-2013 $(1,2)$. Ordlyden i de gjeldende retningslinjene er derfor litt annerledes enn den som refereres av Slørdal \& Spigset. 
Den er nå slik: «When authors submit a manuscript of any type or format they are responsible for disclosing all financial and personal relationships that might bias or be seen to bias their work.» Intensjonen er den samme som tidligere, men ansvaret er lagt enda tydeligere på forfatterne. De er ansvarlige for å redegjøre ikke bare for hva de selv mener kan være en interessekonflikt, men også for hva andre kan oppfatte som en interessekonflikt.

ICMJEs felles interessekonfliktskjema er omarbeidet for å fange opp dette. Forfattere blir bedt om å svare på tre spørsmål. For det første om de på noe tidspunkt har hatt noen interessekonflikter direkte knyttet til det artikkelen omhandler. «På noe tidspunkt» betyr at forfatterne ikke kan påberope seg at de mener at noe er «foreldet» når det gjelder interessekonflikter knyttet til den aktuelle artikkelen. For det andre må forfattere svare på om de har eller har hatt relevante finansielle interessekonflikter som ikke har direkte tilknytning til den aktuelle artikkelen. Absolutt alle slike som forfatterne har hatt de siste tre år, må rapporteres. For det tredje må forfatterne eksplisitt ta stilling til om det er noe mer leserne burde få vite: "Are there other relationships or activities that readers could perceive to have influenced, or that give the appearance of potentially influencing, what you wrote in the submitted work?»

Jeg er derfor enig med Slørdal \& Spigset i at de mulige interessekonflikter som har kommet frem etter at denne artikkelen ble publisert, burde ha vært oppgitt fra starten av.

Så hvordan kan Tidsskriftet sanksjonere hvis forfattere ikke oppgir sine mulige interessekonflikter? Først og fremst ved å sørge for at det hele tiden er mulig å føre debatter som denne i etterkant av at en artikkel er publisert. Og ved å sørge for at denne debatten er direkte koblet til artikkelen, slik at leserne er klar over at det er stilt spørsmål ved om forfatterne har vært tilstrekkelig objektive.
Hvis det skulle vise seg at det tilkommer nye opplysninger som tilsier at artikkelen må rettes opp eller trekkes tilbake, vil dette naturligvis bli gjort.

\section{Charlotte Haug}

charlotte.haug@legeforeningen.no

Charlotte Haug (f. 1959) er sjefredaktør i Tidsskrift for Den norske legeforening.

Ingen oppgitte interessekonflikter.

Litteratur

1. Recommendations for the conduct, reporting, editing, and publication of scholarly work in medical journals. http.//icmje.org/recommendations/ (1.6.2014)

2. Haug C. Krav til forfattere. Tidsskr Nor Legeforen 2013; 133: 1545.

\section{RETTELSE}

Kurs i basale kirurgiske ferdigheter

Saira Mauland Mansoor, Jon-Anders Tunold, Pål Aksel Næss, Erik Trondsen, Christine Gaarder, Jorunn Skattum

Tidsskr Nor Legeforen 2014; 134: 935-7

I Tidsskriftet nr. 9/2014 på side 935 skal det i sammendraget under Resultater stå: Totalt 57 av 65 kursdeltakere ble inkludert i studien. Deltakernes skår var signifikant høyere for alle de tre praktiske øvelsene etter gjennomført kurs sammenliknet med skår før kursdeltakelse (p < 0,001). Selvevalueringen indikerte at deltakerne følte seg mer kompetente etter gjennomført kurs.

Vi beklager feilen. Den er rettet på nett. 